8. Friedman WF, Herschklan MJ, Printz MP et al. Pharmacological closure of patent ductus arteriosus in the premature infant. N Engl J Med 1976; 95 : 526-529

9. Halliday HL, Hirata T, Brady JP. Indomethacin therapy for large patent ductus arteriosus in low birth weight infant : Results and complications. Pediatrics 1979; 64 : 154-159

10. Bhat R, Fisher E, TNK Raju and Vidyasagar $D$. Recent advances in diagnosis and manage- ment of PDA. Ped Clin North Amer 1982; $29: 5,1117-1136$

11. Ivey HH, Kattwinkel J, Park TS et al. Failure of indomethacin to close persistent ductus arteriosus in infants weighing under $1000 \mathrm{gm}$. Br Heart J 1979; 41 : 304-307

12. Cooke RWI, Pickering D. Poor response to oral indomethacin to close patent ductus arteriosus in very low birth weight infants. Br Heart J 1979; $41: 301-304$

\title{
SIMPLE DNA TECHNIQUE FOR DETECTION OF FNTEROTOXIGENIC E. COLI
}

Although enterotoxigenic Escherichia coli (ETEC) is a major cause of acute diarrhea among children in developing countries, the transmission and epidemiology of the disease are poorly understood. The major hindrance to progress has been difficulty in distinguishing toxigenic from nontoxigenic strains. Present detection methods for ETEC, both bacteriological and immunological, depend on demonstration of heat-labile toxin (LT) or heat-stable toxin (ST) production. LT may be detected in tissue culture and by immunological assays. It is also possible to detect the genes encoding for LT and ST production by DNA-DNA hybridisation with radiolabelled DNA probes. None of these assays, however, is well suited to screening large numbers of $E$. coli isolates in modestly equipped laboratories.

A membrane filter assay is described for detection of heat labile toxin (LT) production by $E$. coli. Bacterial colonies were isolated on a membrane filter which was then incubated on an agar medium containing anti-cholera toxin. LT produced by bacterial colonies diffused through the membrane filter, complexed with the antiserum, and formed a zone of precipitation in the agar. Requirements for reagents and materials were simple. The membrane filter assay showed good agreement with both the ganglioside-enzyme-linked immunosorbent assay and the DNA-DNA hybridisation assay and may prove to be an important technique for the study of the epidemiology of enterotoxigenic $E$. coli in developing countries. 